\title{
SELF-REGULATED LEARNING IMPLEMENTED BY THE STUDENTS OF VOCATIONAL HIGH SCHOOL
}

Sari, P.I.M.

English Education Department, Ganesha University of Education

e-mail: indaheed@gmail.com

\begin{abstract}
This study aimed at identifying whether the students of vocational high school in Buleleng sub-district have implemented self-regulated learning or not. Besides, analyzing the mostly implemented aspects of self-regulated learning was the other purpose of this study. The subject of this study were 405 students of vocational high schools in Buleleng sub-district. There were SMKN 2 Singaraja, SMKN 3 Singaraja, and SMK Triatmajaya Singaraja. Descriptive qualitative was used as the design of this study. Some instruments were used, such as questionnaire, observation checklist, and interview guide. The result of this study showed that self-regulated learning has been implemented by $75 \%$ vocational high schools students. Besides, there are three aspects which mostly implemented by students of vocational high school, they are self-control, self-judgment, and self-reaction based on Zimmerman cyclical phase theory
\end{abstract}

Keywords: self-regulated learning, vocational high school, curriculum 2013

\section{INTRODUCTION}

Education is one of the most important things in humans' life. Education in Indonesia was developed from time to time. In formal education, Indonesia has a curriculum as the basic to improve students' development. Khasanah $(2015$, p.3) stated that curriculum is a basis of teaching and learning process. Curriculum accommodates materials, resource, planning instructional content for teaching, and processes for evaluating attainment of educational objectives. Meanwhile, according to Ronald (1996, p.15) stated that the curriculum of the school is the formal and informal content and process by which learner gain knowledge understanding, develop skills, and alter attitude appreciations and values under the auspice of that school. On the other side, according to Peter as cited in Nasution (2003, p.4) curriculum was defined as a plan for providing sets of learning opportunities for persons to be educated. Curriculum can be defined as the best arrangement of education in order to make the best output but, in fact it is commonly changed by the government. It was because the readiness of the implementation of curriculum by the students, teachers, and school itself.

It happened in Indonesia, some changes of curriculum were made by the government to make a good output. Nowadays, many schools in Indonesia implement curriculum 2013 or K-13. This new curriculum was designed by the government in order to build better education in Indonesia. The purpose of the changing to curriculum 2013 from thr previous curriculum was to revise the curriculum KTSP (previous 
curriculum) into a good one. According to Prihantoro (2015, p.78) the curriculum designed was competency based, that is the outcomes-based on the curriculum and therefore the development of the curriculum is geared to the achievement of competencies stated in the graduate competency standards. The learning system of the curriculum is based on the active learning approach that encourages students to do observing, questioning, associating, experimenting, and networking. Students are encouraged to find out, not to be told (discovery learning). In general, Curriculum 2013 contains four elements of change. They are (1) standard of graduate competencies, (2) standard of contents, (3) standard of learning processes, and (4) standard of assessment. Meanwhile, based on Permendikbud No. 67 Tahun 2013, curriculum 2013 is designed to prepare young generation to confront the globalization era. The curriculum 2013 focuses on students' skills and students' knowledge, such as students' critical thinking, students' ability in problem solving, competency of responsibility, competency of communication, and students competency for working and soft skill. So, based on those concepts of curriculum 2013, the governments hope that this new curriculum could make students in Indonesia become autonomous learners and have better quality of education. Further, this curriculum was expected to prepare young generations to confront the 21st century. The existence of 2013 curriculum became a great attention and leads to controversy for most people, because some people regarded curriculum 2013 was not ready yet to be implemented (Mulyasa, 2013, p.35). However, the curriculum change especially curriculum 2013 was purposed to reach better education system and revise the previous curriculum that was curriculum of KTSP. The implementation of 2013 curriculum will run well with the support of teachers/ teacher's staff. The values of 2013 curriculum will be conveyed through them (Nurdin, 2003, p.75). In the implementation of 2013 curriculum, there are three related dimensions. They cannot be separated. They are planning, teaching learning process, and learning evaluation. The planning will establish the materials that will be taught, the media will be chosen, and the methods will be used in teaching learning process. In such away, the evaluation procedures will be used to know the product of teaching learning process and students' achievement.

By implementing curriculum 2013, the government expected a good quality education. In line with curriculum 2013, the method that was used in this curriculum is cooperative learning. According to Johnson \& Johnson (2007, p.7) cooperative learning is the instructional use of small groups so that students work together to maximize their own and each other's learning (Johnson, Johnson, \& Holubec, 1993). Within cooperative learning groups, students discuss the material to be learned with each other, help and assist each other to understand it, and encourage each other to work hard. In addition, this instructional method is related to students' achievements and students cantered.

Besides, one of main characteristics of curriculum 2013 is students cantered. Students-cantered learning means that the students are expected to be more active in the classroom or even in the schools than the teachers. Students are required to be independent in learning process. Students need to be more active in finding the materials and knowledge before their teachers ask them. Students-cantered learning has really close relationship with students' self-regulated learning because when students implement self-regulated learning, the students will be autonomous and the strategy of 
students cantered can be applied. Furthermore, the important thing that students' should do is regulated themselves in learning process.

According to Zimmerman (2002, p.66), self-regulated learning is an activity which is proactively made by the learners, means that they are aware of their strength and limitations. While, according to Schunk \& Zimmerman (1989) self-regulated learning is the degree in which the learners are metacognitively, motivationally, and behaviorally active participants in their learning process. There is now an extensive effort to include motivational constructs along with metacognitive processes in models of self-regulated learning (Schunk \& Zimmerman, 2007) as cited in Zimmerman \& Moylan (2009, p.299). To achieve an academic goal in self-regulation processes, there are self-directed feelings, thoughts, and also behavior. The students or the learners can modify, sustain, and instigate their goal-directed actions which are part of self-regulated learning. The students can practice this strategy for their academic studies. Most importantly, self- regulated learners also manipulate their learning environments to meet their needs (Kolovelonis, Goudas, \& Dermitzaki, 2011) as cited in Sharon Zumbrunn, et al (2011, p.7). However, according to (Zimmerman \& Kitsantas, 2005) as cited in English, M. C. \& Kitsantas, A. (2013, p.129) Self-regulated learners are able to set goals, plan a course of action, select appropriate strategies, self-monitor, and selfevaluate their learning. They are also intrinsically motivated to learn and report high self-efficacy for learning and performance. Besides, Zimmerman \& Moylan (2009, p.299) self-regulated learning refers to self-generated thoughts, feelings, and actions for attaining one's learning goals. By implementing self - regulated learning students will be ready for their lesson in the classroom because they have prepared the material that will be given by the teacher. It also makes the teacher easier to control the students in learning process. In the classroom students demanded to be more active instead of the teacher. If each student implements self -regulated by her/his own, the learning process will run smoothly and get good outcomes.

Furthermore, to support this study the researcher used Zimmerman' theory of selfregulated learning. Moreover, Zimmerman (2002) provides cyclical phases of selfregulated learning. Those phases are used in this study to see how the students regulated themselves. Those phases are forethought phase, performance phase, and self-reflection phase. According to Zimmerman (2002, p.68) forethought phase has two major classes they are task analysis and self motivation. Task analysis involves goal setting and strategic planning, while self-motivation according to Bandura (1997) is stems from students' beliefs about learning, such as self-efficacy beliefs about having the personal capability to learn and outcome expectations about personal consequences of learning. Besides, according to Zimmerman (2002, p.68) performance phase involves two major classes too, these are self-control and self-observation. Then, the last phase is selfreflection phase. Self-reflection phase consists of two major classes; they are selfjudgment and self-reaction.

Based on preliminary observation that the reseracher conducted at SMKN 2 Singaraja, it was found that SMKN 2 Singaraja already implemented curriculum 2013, but almost all of the students still not implement self-regulated learning yet. The teacher still used conventional technique to teach the students (teacher center). So, the researcher interested to conduct a study about self-regulated learning in some vocational schools in Buleleng subdistrict and inspecting which aspect of self regulated learning are mostly implemented by the vocational school students. The researcher conducted 
this study in vocational school because Vocational high school is one of the formal schools in Indonesia which implemented curriculum 2013, so the researcher was curious to identify self - regulated learning of vocational students and analyze the

aspects of self-regulated learning which are mostly implemented by the students of vocational high schools. It is very important to identify self-regulated learning of vocational students because by this study, teacher will know what strategies they used in teaching the students. Those vocational high schools were SMKN 2 Singaraja, SMKN 3 Singaraja, and SMK Triatmajaya Singaraja in Buleleng sub-district. The researcher did an observation, distributed questionnaire, and conducted an interview with some students to find out the implementation of self-regulated learning.

\section{METHOD}

This study was conducted in three vocational high schools which are implemented curriculum 2013 in Buleleng sub-district. Those were SMKN 2 Singaraja, SMKN 3 Singaraja, and SMK Triatmajaya Singaraja. The subject of this study was the students of SMKN 2 Singaraja, SMKN 3 Singaraja, and SMK Triatmajaya Singaraja. The researcher chose the first and second grade students of each those vocational schools respectively. The researcher chose vocational high schools students as subject because they were categorized as adult learners, and their schools were implemented curriculum 2013. The researcher wanted to find out the implementations of self- regulated learning. Furthermore, self-regulated learning has close relationship with cooperative learning and students centered which is connected with curriculum 2013. Meanwhile, the object of this study was vocational high schools students' self regulated learning and the aspects of self-regulated learning based on Zimmerman's cyclical phase which are mostly implemented by the students in their learning process.

This study has two kinds of data. The first one is primary data and the second one is secondary data. The primary data derived from questionnaires which were distributed to 405 students in three vocational high schools in Buleleng sub-district. The result of questionnaire showed that students of vocational high schools implemented selfregulated learning in the learning process. From the questionnaire's result, the researcher also found that there were two phases that were mostly implemented by the students of vocational high schools. Therefore, there was a secondary data which collected from interview's result. The interviewees gave the specific reasons why they mostly choose the statements in performance phase and self-reflection phase.

First, data were collected through the observation in order to find the information about the implementation of self-regulated learning by the student in vocational school during the learning process. The second data collected thorough interview. The researcher conducted the interview section by interviewing the teachers to gather the information about the implementation of curriculum 2013, students' self-regulation, and teachers' perspective about the implementation of self-regulated learning by the students and how the students start to implement the self-regulation.

In transcribing data, the researcher transcribed the data from recorder. All the data were written by the researcher and then analyze the data based on cyclical model theory by Zimmerman. The data were about students and researcher conversation when doing an interview. The interview was about students' reasons why they respond to 'yes' on 
certain statements and support the data of aspects which are mostly implemented by the students of vocational high schools in Buleleng sub-district.

The data elimination took part in this process. The researcher was collected and divided the data. The researcher was eliminated the information which were not significant with the focus of the study. Reducing was used to make the data more focus, deeper and reliable. When analyzing the questionnaire, the researcher found that there were statements which are got highest percentage of respond 'yes' and there were statements which were got lowest percentage. But, the researcher only focused and dug on the statements which were got highest percentage and the follow up activity was doing an interview with the students randomly.

In this process, the final data after reduction were presented descriptively. The data should answer the research question in this study. The researcher used diagrams, tables, and figures to display the data.

All the data such as the observation checklist, questionnaire, and transcription of interview are interpretation used to answer the research question in this study about the identify of self-regulated learning implemented by the students of vocational high schools and the aspects which are mostly implemented by the students of vocational high schools based on cyclical phase theory. (Zimmerman, 2002).

\section{FINDING AND DISCUSSION}

The findings represented all of the data that have been collected. The data collected were divided into two parts based on the research questions; the implementation of self-regulated learning in vocational high school and the aspects of self - regulated learning in the cyclical phases that are mostly implemented by vocational school students. This research was focused in Buleleng Sub-District. There were four vocational high schools that implemented curriculum 2013. Unfortunately, one of them could not be used as subject for this research because they have special regulation. So, for this research only three vocational high schools were used as subjects, they were SMKN 2 Singaraja, SMKN 3 Singaraja, and SMK Triatmajaya which is also known as Mapindo Singaraja. The researcher distributed questionnaires into those three schools. In total, from the three vocational high schools, there were 405 students who were given a questionnaire. The Implementation of Self-regulated learning in Vocational High School

Self-regulated learning is how the students prepare themselves for learning activity before, during, and after the class. In other words, self-regulated learning is how the students think about their planning before the learning process, how they feel during the learning process, and how the students ${ }^{\text {ee }}$ behaved after the learning process in order to attain their learning goals (Zimmerman, 2000). Based on Zimmerman ee theory, there are three cycling phases that students dealing with. First, forethought phase, in this phase students have their own planning for their learning process. There are two major classes in forethought phase process: task analysis and self-motivation beliefs. In task analysis, students plan their goal settings and strategic planning before they come to the class or before learning process, while self-motivation beliefs are about students ${ }^{\text {ee }}$ expectation or value before attending the class or learning process.

The second phase is performance phase. This phase happened during learning process; there are two major classes in performance phase: self-control and selfobservation. Self control is the students ${ }^{\text {ee }}$ deployment or specific strategies that were 
selected during forethought phase, while self-observation refers to students ${ }^{\text {ee }}$ experiment about themselves during the learning process. An example of self- observation is when the students try to find out their comfortable style in studying, whether they will be more comfortable studying with their friends or alone. Third phase is self-reflection phase. In this phase, students do some reflections after learning process. There are two major classes in self-reflection phase: self-judgment and self- reaction. Self-judgment refers to how the students do self-evaluation after learning process such as comparing their score with other friends in order to know how good their performance in certain subject, while self-reaction is studentse ${ }^{\text {ee }}$ satisfying and positive affect regarding their performance.

Therefore, in order to find out the data or to answer the research question about whether vocational high school students implement self-regulated learning based on those cycling phases, the researcher used yes no questionnaire and distributed it to 405 vocational high schools students in Buleleng sub-district. Later on, after distributing questionnaire in order to support the result, the researcher conducted an interview session with the students. The questionnaire consisted of 30 statements which every class has 5 statements. The result shows that vocational high students have implemented self- regulated learning, but each phase did not get the same percentage. The results of the questionnaire above indicated that vocational high schools students implemented cycling phases in self-regulated learning even though in different percentage. One of the statement I will study harder when I get score under KKM) got the highest percentage $(93.8 \%)$ for Yes in questionnaire ${ }^{e e}$ result. That statement belongs to self-reflection phase and self-reaction class. It indicated that vocational high school students mostly doing a reflection after the learning process. The contrary of that, the other statement (I answer the questions on the books before discussing them with the teacher in the class) got the highest percentage $(70.1 \%)$ for No answer in questionnaire ${ }^{e e}$ result. That statement belongs to forethought phase and task-analysis class. It indicated that vocational high schools students were seldom to answer questions on the books before the teacher ask them. In other words, it can be said that the students were lacked of planning before the learning process.

Moreover, close ended questionnaires were distributed to 405 vocational schools students in Buleleng Sub-District. The researcher wanted to know which aspects of selfregulated learning in the cyclical phases are mostly implemented by vocational high school students in Buleleng sub-district. Based on the questionnaire result, the researcher concluded that there were three statements mostly selected by vocational high school students. Those statements were about comfortable sitting position in the classroom, critics acceptance, and reaction if they get score under KKM. Statement about KKM score got the highest percentage which got $93.8 \%$ for Yes answer with statement 'I will study harder when I get score under KKM'. The next place is statement about critics acceptance which statement „I accept critics from my teachers and my friendse got $93.6 \%$ for Yes answer from vocational high schools students. The last place is stated about sitting posistion which statement „I choose comfortable sitting position in the classroom ${ }^{\text {ee }}$ got $91.3 \%$ for Yes answer. Those statements belong to performance phase and reflection phase. Statement about sitting position belongs to self-control aspect of self-performance, statement about critics acceptance belongs to self-judgment of self-reflection, and statement about KKM score belongs to self-reaction of selfreflection too. 
After knowing most statements which are selected by vocational high school students, the researcher concluded that vocational high school students are more openminded in performance phase and self-reflection phase. To ensure those statements, the researcher conducted interviews with some students related to the statements above. The result of the interview is present below:

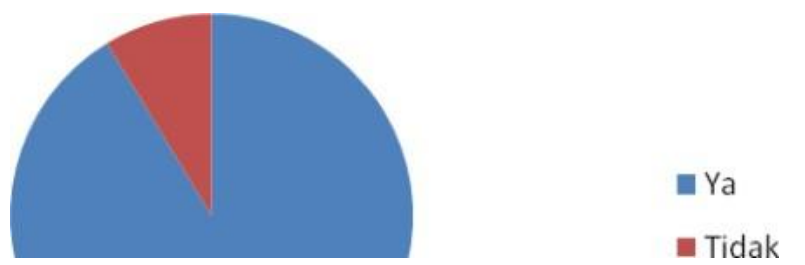

Chart 1. The Percentage Statement about Sitting Position

The chat above shows that position of sitting in the classroom influence students „performance in learning process. It supported by the interviewees who were asked about this statement by the researcher. They selected Yes for statement about sitting position because when they choose where they sit in the classroom by their own, it made them more comfortable in learning. The position mostly choosen by the students is in front of the teacher"e desk. One interviewee (Alit) said that sitting in front of the class or near the teacher"e desk made him more focus in learning, got detailed information from the teacher, and could see the teacher's writing in board clearly.

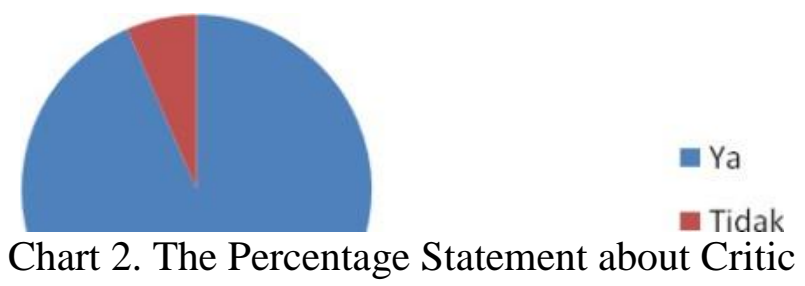

Above is diagram of statement about critic acceptance. Most students selected Yes for this statement. This statement was about they can accepted critics from their teachers and friends. Based on the questionnaire ${ }^{e e}$ result above, the researcher concluded that vocational high schools students are open-minded when they accept critics whether it is from their teacher or their friends. One of the students who was an interviewee said that critics from teachers and friends are very important for their development whether in learning process or socializing. When they got critics from their teachers or friends they will listen first, then decide whether it is good for them or not. If the critics are good for them, they will apply it.

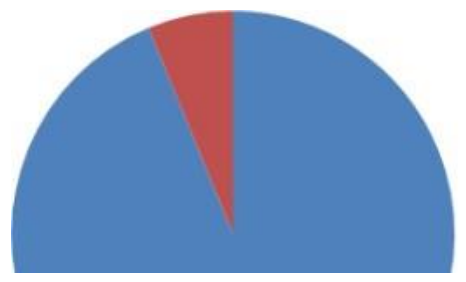




\section{Chart 3. The Percentage Statement about Score}

Above is diagram for statement about score. This statement is the most selected for Yes answer from the students. This statement belongs to self-reflection phase. This statement was about students ${ }^{\text {ee }}$ reaction when they got score under the standard score (KKM). Most of them choose ,they will study harder when they got score under the standard score e. It means vocational high schools students care with their score after the learning process. Besides, the teacher always asks the students who got score under the standard score (KKM) to do improvement (remedial). But, the most common reason why they will study hard if they got low score is because they are ashamed with other friends. One of the students who were an interviewee said that they will feel ashamed if they got low score after learning process, they also said that they want to improve and increase their knowledge. So, that is why students will study harder if they got low score.

Before coming with answer of two research questions, the researcher compared of the results of this study. Based on findings above, the researcher compares the result of questionnaire and the observation that the researcher conducted. Not all of that result of questionnaire reflects the students. It can be said, if the students not understand with the statement in questionnaire or they ashamed to be honest. So, the researcher used interview guide to digging up the data. Next based on finding above, the researcher can answer the research question of this study. First, do vocational high school students implement self-regulated learning? To answer this question, the researcher doing an observation in SMKN 2 Singaraja. This school implemented curriculum 2013. After that, the researcher distributed about 405 questionnaires to three vocational high schools in Buleleng sub-district which implemented curriculum 2013. The result shows that vocational high schools students implemented self-regulated learning. The result can be seen in finding 4.1. The percentage of students result in answering YES higher than the students answering NO for each statement which indicated self-regulated learning.

This result supports other researches about self-regulated learning. In interdisciplinary journal of project based learning there is an article entitled "Supporting Student Self Regulated Learning in Problem and Project Based Learning by English Mary. C \& A. Kitsantas (2013). In this article study, which is about in order to be successful in PBL, students must take responsibility for their own learning process. This includes sel-regulatory processes of sustaining motivation, setting goals, monitoring progress, and engaging in self-reflection. For many students, the use of these processes does not come naturally or easily; therefore, the learning environment and teaching practices in PBL must be designed with intention to support students ${ }^{\text {ee }}$ SRL (Selfregulated learning). So, this article related to statement number 19 which statement „I accept critics from my teachers and my friends ${ }^{\text {ee }}$ by accepting critics from others students can develop their skill and monitoring their progress during the learning process, it means that they aware of learning environment.

However, the other research was conducted by Paul R. Pintrich and Elisabeth V. De Groot (1990) with an article entitled "Motivational and Self-Regulated Learning Components of Classroom Academic Performance" the result showed that student involvement in self-regulated learning is closely tied to students' efficacy beliefs about their capability to perform classroom tasks and to their beliefs that these classroom tasks are interesting and worth learning. At the same time, these motivational beliefs are not 
sufficient for successful academic performance; self-regulated learning components seem to be more directly implicated in performance. So, this research was important in related of those researches. This article support statements number 11 and 25 . Those statements are „I choose comfortable sitting position in the classroom ${ }^{\text {ee }}$ and I will study harder when I get score under $\mathrm{KKM}^{\mathrm{e}}$. Those statements were about students ${ }^{\text {ee }}$ motivation in learning process. When they choose comfortable sitting in classroom, it means they have motivation in learning process. The statement support by one of students" interview, they said 'kalau saya duduk di belakang pandangan bisa tidak terlalu jelas kalau di belakang dan itu yang di belakang kan selalu identik dengan mengobrol jadi gak serius belajar' (If I sit at the back I cannot see clearly and sit at the back is icon for students who like talking during the learning process.). It is also reflection of student ${ }^{\text {ee }} \mathrm{s}$ performance in classroom. The other statement that related to students"e motivation is statement about score, I will study harder when I get score under $\mathrm{KKM}^{\mathrm{ee}}$. Based on interview sessions most of student ${ }^{\mathrm{ee}}$ reasons is because they ashamed if they got low score in learning process and the other reasons is because schoole regulation about KKM. If students got score under the KKM, they will pass remedial test until they got score higher than KKM. Based on article above motivation is very closed to self-regulated learning, student involvement in self-regulated learning is closely tied to students' efficacy beliefs about their capability to perform classroom tasks. Otherwise, if students have motivation and they implemented self-regulated learning then they will easily to get their achievements.

After distributing questionnaire for those three vocational high schools, researcher chooses three statements which got highest percentage. Those three statements are statement about sitting position, statement about critic acceptance, and statement about score. Most studentse belief if they choose the sitting position by their own, it will affect their motivation to study and it also influence their achievement in classroom during learning process. Moreover, students said that it was very important for their developed in learning process and in their socializing activity. Furthermore, if they got score under the KKM, they will study harder to reach the goal of KKM or higher score than before. Students think that score is very important of their learning process. So, they will study harder than before to reach high score.

\section{CONCLUSION}

Based on findings and discussion in chapter IV, the result of analysis showed that self-regulated learning was implemented by vocational high school students in Buleleng sub-district. The questionnaires' result showed that there were some statements which got higher percentages for YES answer than NO answer. It indicated that students of vocational high schools implemented self-regulated learning in their learning process. In self-regulated learning there are three phases that students have in learning process, they are forethought phase, performance phase, and self-reflection phase. Two of the three phases were mostly chosen by the students of vocational high schools in Buleleng subdistrict, they were performance phase and self-reflection phase. This study used questionnaire, observation, and interview to get all of the data. So, the researcher can conclude that students from three vocational high schools in Buleleng sub-district, they are SMKN 2 Singaraja, SMKN 3 Singaraja, and SMK Triatmajaya, which implemented 
curriculum 2013 were implemented self-regulated learning and two of the three phases in self-regulated learning were mostly chosen by vocational high schools students.

There are several suggestions that can be conveyed by the researcher which can be seen as the followings: It is very important for students to know how to implement selfregulated learning and what are the aspects. Students should be more independent and responsible of their learning process in order to make them comfortable during the learning process. To increase their critical thinking, students must plan, performed, and do reflection for them in learning process. It influences the output of education, if students implemented self-regulated learning as well they will got high achievement.

It is very important for teachers to support their students in implementing selfregulated learning. If the teachers know aspects of self-regulated learning the researcher hope that teachers can help or support the students to increase their self- regulated learning by using some strategies. It will help teacher to teach and guide the students during learning process.

It is very important for other researchers who would like to do a research about implementations of self-regulated learning can use this study as a guidance to be more specific in finding the data. Other researchers also can develop this study by using teachers as subject, so the topic of self-regulated learning not only seen in students' side but also in teachers' side.

\section{REFERENCES}

Hancock,B., Ockleford,E., and Windridge,K. (2009). An Introduction to Qualitative Research. Nottingham

Parkinson, G., \&Drislane, R. (2011). Qualitative research. In Online dictionary of the social sciences. Retrieved from http://bitbucket.icaap.org/dict.pl . Accessed on May 82015

Zumbrunn, S., Tadlock, J., \& Roberts, E. D. (2011). Encouraging Self-Regulated Learning in the Classroom. Metropolitan Educational Research Consortium (MERC), Virginia Commonwealth University, 28.

Khasanah, I. N. (2015). The Implementation Of 2013 Curriculum By The English Teacher And Its Barriers (A Case Study At The 10th Grade Of Sma N 1 Rembang In 2014/2015 Academic Year). 135. http://www.write.com/writingguides/research-writing/research-process/datatriangulation-how-thetriangulation-of-data-strengthens-your-research/

Groot, P. R. P. a. E. V. D. (1990). Motivational and Self-Regulated Learning Components of Classroom Academic Performance. Journal of Educational Psychology, 82(1), 33-40.

English, M. C., \& Kitsantas, A. (2013). Supporting Student Self-Regulated Learning in Problem- and Project-Based Learning. Interdisciplinary Journal of ProblemBased Learning, 7(2), 24. doi: 10.7771/1541-5015.1339

Suaphan, P. (2015). Why I Choose A Vocational School: The Study Of Elicited Expectation And Educational Decision.

E. Mulyasa, Pengembangan dan Implementasi Kurikulum 2013, (Bandung: Remaja Rosdakarya, 2013), p. 35.

Yeasmin, S., \& Rahman, K. F. (2012). 'Triangulation' Research Method as the Tool of Social Science Research. BUP JOURNAL, 1(1), 10. 